\title{
Analysis of Customer Complaints on Access, Paramedic Interpersonal Service, and Facilities of Service on The Incidence Forced Discharge
}

\author{
Khairunnisa *, Izaak Zoelkarnaen Akbar **, Triawanti ${ }^{\text {**** }}$, Husaini *, Fauzie Rahman **** \\ * Master of Public Health, Faculty of Medicine, Lambung Mangkurat University, Indonesia \\ ${ }^{* * *}$ dr. HM Ansari Saleh Regional General Hospital, South Kalimantan, Indonesia \\ **** Department of Biomechemistry, Faculty of Medicine, Lambung Mangkurat University, Indonesia \\ **** Public Health Study Program, Faculty of Medicine, Lambung Mangkurat University, Indonesia \\ DOI: 10.29322/IJSRP.10.08.2020.p104122 \\ http://dx.doi.org/10.29322/IJSRP.10.08.2020.p104122
}

\begin{abstract}
Incidence forced discharge is the request of the patient or the patient's family to go home before his illness cured. In 2019, incidence discharge was $9.36 \%$ to 122 cases per month or 1461 . It is not compatible with the standards of the Minister of Health Decree No. 129 Years 2008, i.e. incidence forced discharge is $\leq$ $5 \%$. As for the impact of the discharge incident, one of them is the quality of service. The purpose of this study is to analyze the effect of access, interpersonal services of paramedics, service facilities and customer complaints on forced discharge at the Inpatient Installation of the Ratu Zalecha Martapura Regional Hospital. This research is a quantitative observational analytic study with a cross-sectional design. The number of samples for a large sample of hypotheses for two proportions of the population was 222 respondents with the sampling technique was accidental sampling. There was a partial effect of service access $(p=0.033)$, interpersonal services of paramedics $(\mathrm{p}=0.028)$, service facilities $(\mathrm{p}=0.046)$ and customer complaints $(\mathrm{p}=0.042)$ on forced discharges. Results showed no effect of these variables simultaneously on the incidence of forced discharge is $(p=0.000)$ with $\mathrm{p}<0.05$, where the variable access to services $(\mathrm{p}=0.033)$ and Exp.B (2.665) is the most dominant variable influence on forced discharge incident. There is a partial and simultaneous influence of access, interpersonal services of paramedics, service facilities and customer complaints on forced discharge, with service access as the dominant variable causing the forced discharge.
\end{abstract}

Index Terms- service access, interpersonal services of paramedics, service facilities, customer complaints, forced discharge

\section{INTRODUCTION}

$\mathrm{F}$ orced discharges are known as discharge at self-request and are considered a phenomenon in which patients leave the hospital without medical advice (1). Forced discharges are caused by a gap between expectations and services provided so that the follow-up that can be taken by consumers is to either move or leave the place of service accompanied by complaints or non- reported complaints (2). According to Kotler (2009), the incidence of forced discharges compared to discharged with the agreement of a medical mathematically ranges from a ratio of 1: 9 (3). Although the number of forced discharged events is considered to have a lower number, based on the Minister of Health Decree No. 129 of 2008, the forced discharged at the hospital must meet the standard $\leq 5 \%$. The incident of forced discharge certainly does not only harm patients but also on hospitals which is one of the factors that can affect the quality of service.

Accredited hospitals must continue to monitor inpatient care standards, especially those for forced discharges through the Minimum Service Standards (4). Inpatient installation at Ratu Zalecha Martapura Regional Hospital became the target of the study due to inpatient service issues that indicated the incidence forced discharge. In 2019, incidence discharge was $9.36 \%$ to 122 cases per month or 1461. It is not compatible with the standards of the Minister of Health Decree No. 129 Years 2008, i.e. incidence forced discharge is $\leq 5 \%(6)$.

Ratu Zalecha Martapura Regional General Hospital continues to make improvements to reduce the number of dissatisfaction services, one of which is by facilitating customer complaints. Indicators of customer complaints can be seen through inpatient customer satisfaction surveys, namely the value of the Community Satisfaction Index. In 2019, $80.61 \%$ of SMEs that are not following the standards of the Minister of Health Decree (6) with a service element item of "Appropriateness of Care" service quality was average $\mathrm{C}$ with 3,010 votes more low compared to other service element items. Based on the 2019 Public Complaints Report, there were 62 complaints from 1461 patients being forced to go home. Inpatient Installation got the highest number of complaints, 33 complaints. It is undeniable that there are still many customers who are less satisfied with health services and are not documented as hospital evaluation materials. The highest source of complaints comes from problems which include (1) Service facilities with 13 complaints, (2) Access to services with ten complaints, and (3) interpersonal services of paramedics with ten complaints. 


\section{RESEARCH METHOD}

This research approach uses quantitative observational analytic research. The design method uses a cross-sectional study design used to analyze customer complaints about access, interpersonal services of paramedics, and service facilities for forced discharge. Research using survey methods. The population in this study was the family of inpatients in the study period in the Inpatient Installation of the General Hospital of Ratu Zalecha Martapura in 2020. Determination of the sample size used the Lemeshow Formula, 1991 for the sample size of the hypothesis of two population proportions namely 222 respondents, and sample size added $10 \%$ to anticipate samples that drop out or have missing data. The sampling technique in this study uses accidental sampling. Data analysis used the chis-quare test as a bivariate analysis and multiple logistic regression tests as a multivariate analysis.

\section{FINDINGS}

Table 1. The Characteristic of Respondents

\begin{tabular}{|c|c|c|c|}
\hline Variable & Category & Freq & $\%$ \\
\hline \multirow[t]{2}{*}{$\begin{array}{l}\text { Incidence } \\
\text { Discharge }\end{array}$} & Forced Discharge & 44 & 19.8 \\
\hline & Not a Forced Discharge & 178 & 80.2 \\
\hline \multirow[t]{2}{*}{ Service Access } & Hard to Access & 114 & 51.4 \\
\hline & Easy to Access & 108 & 48.6 \\
\hline \multirow[t]{2}{*}{$\begin{array}{l}\text { Paramedic } \\
\text { Interpersonal } \\
\text { Services }\end{array}$} & Bad Service & 132 & 59.5 \\
\hline & Good Service & 90 & 40.5 \\
\hline \multirow[t]{2}{*}{ Service Facilities } & Inadequate Facilities & 117 & 52.7 \\
\hline & Adequate Facilities & 105 & 47.3 \\
\hline \multirow[t]{5}{*}{$\begin{array}{l}\text { Customer } \\
\text { complaint }\end{array}$} & Complaints & 116 & 52.3 \\
\hline & 1. Service Access & 42 & 35.9 \\
\hline & $\begin{array}{l}\text { 2. Paramedic } \\
\text { Interpersonal Services }\end{array}$ & 34 & 33.7 \\
\hline & 3. Service Facilities & 22 & 33.3 \\
\hline & No Complaints & 106 & 47.7 \\
\hline
\end{tabular}

Table 2. Bivariate Analysis with Chi-Square and Fisher Exact

\begin{tabular}{|c|c|c|c|c|c|}
\hline \multirow{2}{*}{$\begin{array}{c}\text { Variab } \\
\text { le }\end{array}$} & \multicolumn{2}{|c|}{$\begin{array}{c}\text { Chronic Energy } \\
\text { Deficiency }\end{array}$} & \multirow[t]{2}{*}{$\mathbf{N}$} & \multirow[t]{2}{*}{$\begin{array}{c}p- \\
\text { value }\end{array}$} & \multirow[t]{2}{*}{$95 \%$ CI } \\
\hline & SEZ & No SEZ & & & \\
\hline
\end{tabular}

Service Access

\begin{tabular}{|c|c|c|c|c|c|c|c|}
\hline $\begin{array}{l}\text { Hard to } \\
\text { Access }\end{array}$ & 30 & 25.6 & 87 & 74.4 & 117 & \multirow[t]{2}{*}{0.033} & \multirow[t]{2}{*}{$\begin{array}{l}2.241(1.114 \\
-4.510)\end{array}$} \\
\hline $\begin{array}{l}\text { Easy to } \\
\text { Access }\end{array}$ & 14 & 13.3 & 91 & 86.7 & 105 & & \\
\hline $\begin{array}{l}\text { Bad } \\
\text { service }\end{array}$ & 27 & 26.7 & 74 & 73.3 & 101 & \multirow[t]{2}{*}{0.028} & \multirow[t]{2}{*}{$\begin{array}{l}2.232(1.135 \\
-4.389)\end{array}$} \\
\hline $\begin{array}{l}\text { Good } \\
\text { service }\end{array}$ & 17 & 14.0 & 104 & 86.0 & 121 & & \\
\hline
\end{tabular}

Service Facilities

\begin{tabular}{|c|c|c|c|c|c|c|c|}
\hline $\begin{array}{l}\text { Inadeq } \\
\text { uate }\end{array}$ & 19 & 28.8 & 47 & 71.2 & 66 & \multirow[t]{2}{*}{0.046} & \multirow[t]{2}{*}{$\begin{array}{c}2.118(1.070 \\
-4.195)\end{array}$} \\
\hline $\begin{array}{l}\text { Adequa } \\
\text { te }\end{array}$ & 25 & 16.0 & 131 & 84.0 & 156 & & \\
\hline \multicolumn{8}{|c|}{ Customer complaint } \\
\hline Yes & 23 & 27.4 & 61 & 72.6 & 84 & \multirow[t]{2}{*}{0.042} & 2.101 \\
\hline No & 21 & 15.2 & 117 & 84.8 & 138 & & $\begin{array}{c}(1.077- \\
4.096)\end{array}$ \\
\hline
\end{tabular}

Based on Table 2, it can be seen that there are variables that have an influence on the incidence of forced discharges at the Inpatient Installation of the Ratu Zalecha Martapura Regional General Hospital, namely access to services (sig. $=0.033$ ) with 95\% CI 2.241 (1.114 - 4.510), interpersonal services of paramedics (sig. $=0.028)$ with 95\% CI $2.232(1.135-4.389)$, service facilities (sig. $=0.046)$ with $95 \%$ CI $2.118(1.070-4.195)$, and customer complaints (sig. $=0.042)$ with $95 \%$ CI $2.101(1.077$ - 4.096).

\begin{tabular}{cllccc} 
Table 3. Multivariate Analysis & & & & \\
\hline \multirow{2}{*}{ Step } & Research variable & Wald & B & Exp (B) & Sig. \\
\cline { 2 - 5 } 1 & Service Access & 6.760 & 0.980 & 2.665 & 0.000 \\
\cline { 2 - 5 } & Interpersonal Service & 6.831 & 0.952 & 2.590 & \\
\cline { 2 - 5 } & Service Facilities & 5.382 & 0.863 & 2.369 & \\
\cline { 2 - 5 } & Customer complain & 6.999 & 0.965 & 2.624 & \\
\cline { 2 - 3 } & Constant & & -4.348 & 0.013 & \\
\hline
\end{tabular}

$$
\mathrm{Y}=-4,348+0,980 \mathrm{X} 1+0,952 \mathrm{X} 2+0,863 \mathrm{X} 3+0,965 \mathrm{X} 4+\varepsilon
$$

Based on Table 3, it is known that the value of sig. $<0.05$, it can be concluded that service access, interpersonal service of paramedics, service facilities and customer complaints simultaneously influence the incidence of forced discharge and of all the independent variables that most dominantly affect the incidence of forced discharge are service access variables ( $\mathrm{p}$-value $=0.033$ ) with a beta exponent value (Exp. B) of 2.665, meaning that access to services will be 2.665 times resulting in the occurrence of forced discharge.

\section{DISCUSSION}

Hard service to health access will certainly have an impact on customer expectations so that it will cause dissatisfaction with service (7). There are several indicators of service access that are the cause of service dissatisfaction, namely procedures, completion time, costs, products, facilities and infrastructure as well as service provider competencies (8). Access to health services "hard" and "forced discharge" rated by 30 respondents (25.6\%), it is in line with the theory of Fornell and Westbrook (1984) (9). Access to health services "hard" and "no forced discharge" was assessed by 87 respondents (74.4\%), which was due to other factors that made service recipients rethink their decision to leave the hospital without medical approval. Access to health service "easy" and "forced discharge" services was assessed as many as 14 respondents (13.3\%), this was due to other factors 
that made it possible for the occurrence of forced disasters other than access to services, according to Nofiyanto, Utami and Koeswo (2014) such as equipment health, facilities of health, system management and employees, communication or delivery service, attitude/behavior, food service, facility inpatient room, access into the hospital, scheduling service time and time of visits , treatment or diagnosis, and service fees (10). While access to services "easy" and "no forced discharge" valued as much as 91 respondents $(86.7 \%)$.

The interpersonal service of paramedics is an indicator of health services that can be a priority in determining patient dissatisfaction (7). Meanwhile, if this is not fulfilled, it will cause an indication of a forced discharge. The interpersonal services of paramedics "not good" and "forced discharge" were assessed by 27 respondents $(26.7 \%)$, similar to the research conducted by Lubis and Simanjorang (2018) (11). Interpersonal care paramedics "not good" and "no forced discharge" in value by 74 respondents (73.3\%). The probable reasons why respondents did not go home were because the patient or the patient's family still demanded the use of paramedical personnel interpersonal services better than before, the patient's condition did not allow for forced discharges and risk concerns if forced discharge and the patient's illness increased weight (10). The interpersonal services of paramedics "good" and "forced discharge" were assessed as many as 17 respondents (14\%), this was due to other factors that made the occurrence of forced disasters occur apart from interpersonal services of paramedics, according to Sulistyawati (2016), there are several indicators of interpersonal services of paramedics who are the cause of service dissatisfaction, namely medical services, nonmedical services, attitudes, information delivery, visit rates, and so on (7). While interpersonal care paramedics "good" and "no forced discharge" valued as much as 104 respondents (86.0\%).

Inadequate service facilities indicate the level of health care and facilities obtained and cannot be enjoyed by patients/families in the hospital. So this is a determinant of service dissatisfaction (6). Service facilities are rated as "inadequate" and "forced discharge" is valued by 19 respondents $(28.8 \%)$, similar to the research conducted by Lubis and Simanjorang (2018) (11). Service facilities rated as "inadequate" and "no forced discharge " were rated by 74 respondents $(73.3 \%)$. This refutes the theory of Mohseni et al. (2015) explained that the main reason relating to the occurrence of forced discharges was due to relationships within the hospital (such as inadequate equipment and environmental facilities) (12). Service facilities are rated as "adequate" and " forced discharge" are valued by 25 respondents $(16.0 \%)$, this is due to other factors that make it possible for the occurrence of forced disasters other than service facilities, according to Azar, et al. (2017) variables outside the research that empirically underlie the occurrence of forced discharges, include the atmosphere of the patient's environment, physical facilities, attractive infrastructure, having the latest medical equipment, and cleanliness (13). Whereas, service facilities were rated as "adequate" and "no forced discharge" valued by 131 respondents $(84.0 \%)$.

Customer complaints will certainly have an impact on the decision to make a forced discharge from the hospital (13), with complaints such as access to services, interpersonal services of paramedics and service facilities (15). Customer complaints are rated "complaint" and "forced discharge" are assessed by 23 respondents $(27.4 \%)$, similar to research conducted by Lubis and Simanjorang (2018) (11). Customer complaints are rated "complaint" and "no forced discharge" in value by 61 respondents (72.6\%). According to Marlina (2017), there is a feeling of dissatisfaction and did not leave the hospital because the customer provides the opportunity for service providers to return customer satisfaction (13). Customer complaints are rated "no complaints" and "forced discharge" are valued by 21 respondents $(152 \%)$, this is due to other factors that make possible the occurrence of forced disasters other than customer complaints, according to Fornell and Westbrook's theory (1984), concerning catering, environmental, professional and technical care, service personalization and accessibility (9)whereas customer complaints were assessed as "no complaints" and "non forced discharges" valued by 117 respondents $(84.8 \%)$.

Service access, interpersonal services of paramedics, service facilities and customer complaints affect the incidence of forced return. This is consistent with the explanation by Fornell and Westbrook's theory (1984: 68) (9). Therefore patient dissatisfaction due to complaints due to mismatches to customer expectations and the reality both in terms of service access, interpersonal services of paramedics and forced discharged should be eliminated to avoid any forced disasters that will negatively impact health care agencies

\section{CONCLUSION}

1. Access to services affects the incidence of forced discharges in the inpatient installation at Ratu Zalecha General Hospital Martapura $(\mathrm{p}=0.033)$.

2. The interpersonal services of paramedics affected the incidence of forced discharges at the inpatient installation at the Ratu Zalecha General Hospital Martapura $(\mathrm{p}=0.028)$

3. Service facilities affect the incidence of forced discharges at the inpatient installation at the Ratu Zalecha General Hospital Martapura $(\mathrm{p}=0.046)$.

4. Customer complaints affect the incidence of forced discharge at the inpatient installation at the Ratu Zalecha General Hospital Martapura ( $\mathrm{p}=0.042)$.

5. Access to services, interpersonal services of paramedics, service facilities and customer complaints also significantly affected the simultaneous incidence of forced discharge $(\mathrm{p}=$ $0.000)$

6. The independent variables that most dominant influenced the incidence of forced discharge were access to services ( $\mathrm{p}=$ $0.033)$ and $($ Exp. $B=2.665)$.

\section{REFERENCES}

1. Lekas, HM, Alfandre, D., Gordon, P., Hrwood, K., \& Yin, MT (2016). The Role of Patient-Provider Interactions: Using an Accounts Framework to 
Explain Hospital Discharge Against Medical Advice. Journal Elsevier. Vol. 01 (01): 106-113.

2. Emeka, IE, and Eze, FC (2018). Using the Servqual Model to Evaluate the Service Delivery of the Consumer Protection Council in Nigeria. European Journal of Business and Management. Vol. 10 (18): 91-98.

3. Kotler, P., and Keller, KL (2009). Marketing Management Volume 2. Erlangga. Jakarta

4. Fitrirachmawati. (2017). The Relationship between Supervision and Nurse Compliance Function Performing Patient Identification SOP in Dr. Mohammad Hoesin Palembang Hospital in 2015. Journal of Indonesian Hospital Administration. Vol. 03 (02): 78-87.

5. Hidayat, TN (2019). Profile of the Ratu Zalecha General Hospital Martapura in 2019. [pdf]. URL: http://rsraza.banjarkab.go.id , accessed September 1, 2019.

6. Ministry of Health Republic of Indonesia. (2008). Minister of Health of the Republic of Indonesia Decree Number: 129 / Menkes / SK / II / 2008 concerning Minimum Service Standards for Hospitals.

7. Sulistyawati, T. (2016). Patient's Perception of Ex. Askes Towards Quality of Service Before and After the Implementation of the National Health Insurance at the Bandarharjo Health Center in Semarang City (Case Study in the Working Area of the Bandarharjo Health Center). Semarang State University. Semarang.

8. Sutopo. (2014). The Importance of Information Systems on Public Services for the Community. Journal of Rural and Development. Vol. 05 (01): 15-26.

9. Fornell and Robert A. Westbrook. (1984). The Vicious Circle of Consumer Complaints, Journal of Marketing, Vol. 48 (01): 68-78.

10. Nofiyanto, E., Utami, EW and Koeswo, M. (2014). Differences in Patients' Health Perceptions are the Main Reason for Forced Discharge. Brawijaya Medical Journal. Vol. 28 (01): 114-118.

11. Lubis, MFS, and Simanjorang, A. (2018). Factors That Influence Forced Discharge by Patient Request in Inpatients at Madani General Hospital, Medan City. Medical Record Journal. Vol. 01 (02): 53-63.

12. Azar, I., Jahani, Y., Rafiei, S., Masoud, A., and Vali, L. (2017). Evaluating Health Service Quality: Using Importance Performance Analysis.
International Journal of Health Care Quality Assurance. Vol.30 (07): 656663.

13. Mohseni, M., Alikhani, M., Tourani, S., Aghdash, USA, Royani, S., \& Joo, MM (2015). Rate and Causes of Discharge Against Medical Advice in Iranian Hospitals: A Systematic Review and Meta-Analysis. Iran J. Public Health. Vol. 01 (01): 902-912.

14. Marliana, L. (2017). Analysis of the Management of Patient Complaints Services to the Quality of Health Services in Regional Hospitals. AM Parikesit Tenggarong. Administrative Reform Journal. Vol. 05 (02): 69-78.

15. Carnevalli, JA, and Miguel, PC (2008). Review, Analysis and Classification of The Literature on QFD Types of Research, Difficulties and Benefits. International Journal of Production Economics. Vol. 114 (02): 737-754..

\section{AUTHORS}

First Author - Khairunnisa, Master of Public Health, Faculty of Medicine, Lambung Mangkurat University, Indonesia.

Second Author - Izaak Zoelkarnaen Akbar, dr. HM Ansari Saleh Regional General Hospital, South Kalimantan, Indonesia.

Third Author - Triawanti, Department of Biochemistry, Faculty of Medicine, Lambung Mangkurat University, Indonesia.

Fourth Author - Husaini, Master of Public Health, Faculty of Medicine, Lambung Mangkurat University, Indonesia.

Fifth Author - Fauzie Rahman, Public Health Study Program, Faculty of Medicine, Lambung Mangkurat University, Indonesia. Correspondence Author - Khairunnisa, Master of Public Health, Faculty of Medicine, Lambung Mangkurat University, Indonesia, email: emailkhairunnisa @ gmail.com 